\title{
An Anatomy of Working Capital and Profitability of Aurabindo Pharma
}

\author{
Rupam Soni \\ Junior Research Fellow, Gujarat University, School of Commerce, Navrangpura, Ahmedabad 380009 Gujarat, India
}

\begin{abstract}
Thomas A. Edison once said "If there's a way to do it better, find it". Earning profit is the main objective of every business. Profitability affects by many factors but the operation of business play a vital role. Working capital is required for day to day business operation. For the motive of unlocking the link between working capital and profitability this study has been carried out. This research is mainly focus on the working capital analysis and profitability of Aurobindo Pharma for the period of 10 years from 2008-09 to 201718. Ratio analysis techniques have been used to evaluate the financial statements of the company. The findings indicate a significant positive relationship between Profitability ratio and number of days in receivable.
\end{abstract}

Keywords: Working Capital, Efficiency, Profitability

\section{Introduction}

In any type of business there are mainly two types of capital-

- Fixed capital

- Working capital

Fixed capital is the capital required for purchasing and acquisition of fixed assets such as land, building, machinery etc.

Working capital is the capital required for day to day working in a business concern such as purchasing raw materials, paying wages and salary, payment to suppliers. It is a challenge for every manager to keep the working capital flowing as per the requirement in the business as it is considered to be life blood of the business. Thus, need for working capital to run day-to-day business activities smoothly can't be neglected.

In practically, some part of working capital is predetermined in nature such as stock kept as minimum margin stock/ safety stock, minimum balance of cash, minimum balance of bank accounts etc. This predetermined working capital is also treated as current assets but the business cannot use it in dayto-day operation of business activities. The motive of this part of working capital is only to run business smoothly in contingency situations like shortage of raw materials, to meet seasonal demand of product, to meet unexpected cash expenses etc.

Now, the question crop up that "Why the working capital is essential?"

Working capital is essential because it is connected from the process of the production to selling of finished goods along with recovery from Debtors, at all the stages of business cycle, liquidity must be needed to efficiently run the business. Profitability is influence by working capital cycle, thus management of working capital is an instrument to manage the profitability of the business.

\section{Literature Review}

Deloof (2003) ${ }^{[1]}$, investigated the relation between WCM and corporate profitability for a sample of 1,009 large Belgian non-financial firms for the 1992-1996 period. The author concluded this study with the finding of significant negative relation between gross operating income and the number of days accounts receivable, inventories and accounts payable of Belgian firms. Deloof recommended that managers can create value for their shareholders by reducing the number of days accounts receivable and inventories to a reasonable minimum

Lazaridis and Tryfonidis (2006) ${ }^{[2]}$, investigated relationship between working capital management and profitability of 131 listed companies in the Athens Stock Exchange for the period of 2001-2004. They found a negative relationship between corporate profitability and the cash conversion cycle it means that less profitable firms wait longer to pay. They also found negative relationship between number of days in inventory and corporate profitability.

Alipour (2011) ${ }^{[3]}$, studied the relationship between working capital management and profitability of 1063 selected companies listed on Tehran stock exchange for the period of 2001-2006.The finding indicate that profitability have significant negative relation with days of account receivables and inventory turnover days. Moreover direct significant relation found between number of day's accounts payables and profitability. Researcher suggested that the managers can create value for shareholders by means of decreasing receivable accounts and inventory.

Arunkumar(2013) ${ }^{[4]}$, analyzed the effect of working capital management on the profitability of for 1198 manufacturing firms listed in Centre for Monitoring Indian Economy for a period of 5 years. They found a positive relationship between return on assets and debtor's days and inventory days and Creditor's days showed a significant negative relationship with return on assets. They suggested that long number of days of accounts payable leads the firm to a low level of profitability and vice versa.

Volume 7 Issue 12, December 2018

www.ijsr.net

Licensed Under Creative Commons Attribution CC BY 


\section{International Journal of Science and Research (IJSR) \\ ISSN: 2319-7064}

Index Copernicus Value (2016): 79.57 | Impact Factor (2017): 7.296

Enqvist et al. (2014) ${ }^{[5]}$, examined the impact of working capital management on firm profitability in different business cycle in Finland for the period of 18 years. This study mainly focused on the profitability, business cycle, receivables and payables conversion period. They observed more profitable Finnish companies utilize cash discounts on payables and do not use accounts payable trade credit as a source of financing and the importance of accounts payable in relation to profitability does not vary according to the stage of the business cycle. The relationship between the current ratio $(C R)$ and profitability is found to be positive and statistically significant for all of the first four regressions.

Pais et al. (2015) ${ }^{[6]}$, studied the effects of working capital management on the profitability of selected 6063 small and medium-sized Portuguese firms for the period of 2002-2009. They found a reduction in the inventories held and in the number of days that firms take to settle their commercial liabilities and to collect payments from its customers are associated to higher corporate profitability. They suggested that more aggressive working capital management policies increase firms' profitability.

Sivashanmugam et al. (2016) ${ }^{[7]}$, examined the working capital management strategies and profitability of 35 Indian cement companies for the period of 5 years from 2010 to 2014. The finding highlights the importance of efficient working capital management practices to improve the profitability of companies. The results revealed that cash conversion cycle of a company has a negative correlation with its profitability. They also suggested that managers can improve the profitability by decreasing the number of day's receivables and increasing the inventory turnover in days.

\section{Research Gap:}

Numerous studies on working capital analysis were undertaken in relation to profitability, efficiency of the management. However, the requirement of working capital have been changing with time thus, this study is dealing with recent span of time and its future aspects.

\section{Research Methodology}

\subsection{Objectives of the study}

a) To measure the impact of working capital cycle on profitability of the selected company.

b) To study the component of working capital and their individual impact on profitability of the selected company.

\subsection{Hypothesis of the study}

H0-1: There is no association between Cash conversion cycle and Profitability ratio of selected company.

H1-1: There is association between Cash conversion cycle and Profitability ratio of selected company.

Ho-2: There is no association between working capital components and Profitability ratio of selected company.

H1-2: There is association between working capital components and Profitability ratio of selected company.

\subsection{Data and Variables}

This study uses the financial data of Aurobindo Pharma for the period of 10 year from 2008-09 to 2017-18.

Company Profile: Aurobindo Pharma became a public company in 1992 and listed its shares on the Indian stock exchanges in 1995. A well-integrated pharma company, Aurobindo Pharma features among the top 2 Pharmaceutical companies in India in terms of consolidated revenues. Aurobindo exports to over 150 countries across the globe with around $90 \%$ of revenues derived from international operations.

To measure the impact of working capital on profitability, the following measures have been taken-

Table 1: Variable used in the study

\begin{tabular}{|c|c|c|}
\hline S. No & Variable & Calculation Method \\
\hline \multicolumn{3}{|c|}{ Working Capital Measures } \\
\hline 1 & $\begin{array}{l}\text { Number of Days in } \\
\text { Receivable }\end{array}$ & 365/ Debtor Turnover Ratio \\
\hline 2 & $\begin{array}{l}\text { Number of Days in } \\
\text { Inventory }\end{array}$ & 365/ Inventory Turnover Ratio \\
\hline 3 & $\begin{array}{l}\text { Number of Days in } \\
\text { Payable }\end{array}$ & 365/ Creditor Turnover Ratio \\
\hline 4 & $\begin{array}{l}\text { Cash Conversion Cycle/ } \\
\text { Working Capital Cycle }\end{array}$ & $\begin{array}{c}\text { Number of Days in Receivable+ } \\
\text { Number of Days in Inventory - } \\
\text { Number of Days in Payable }\end{array}$ \\
\hline \multicolumn{3}{|c|}{ Profitability Measures } \\
\hline 5 & Profit on Sales Ratio & Profit After Tax/Total Sales $* 100$ \\
\hline 6 & Return On Equity & $\begin{array}{c}\text { Profit After Tax/Equity Share } \\
\text { Capital } \\
\end{array}$ \\
\hline 7 & Earning Per Share & \begin{tabular}{|c|} 
Profit available for Equity \\
Shareholders/ Number of Equity \\
shareholders
\end{tabular} \\
\hline
\end{tabular}

\subsection{Limitations of the study}

The study is based on the annual reports provided by company on the website. Thy company is a big player of Pharmaceutical Industry of India so the finding may not relevant for other industry because there is chances of changing in business pattern of different industries. Researcher has no intension to challenge any previous studies.

\section{Data Analysis}

Table 2 shows the value of working capital measures which are number of days in receivable, number of days in inventory and number of days in payable for the period of 10 years. It also shows cash conversion cycle of the company.

Table 2: Working Capital Measures

\begin{tabular}{|c|c|c|c|c|}
\hline Year & $\begin{array}{c}\text { Number of } \\
\text { Days in } \\
\text { Receivable }\end{array}$ & $\begin{array}{c}\text { Number of } \\
\text { Days in } \\
\text { Inventory }\end{array}$ & $\begin{array}{c}\text { Number of } \\
\text { Days in } \\
\text { Payable }\end{array}$ & $\begin{array}{c}\text { Cash } \\
\text { Conversion } \\
\text { Cycle }\end{array}$ \\
\hline 2009 & 71.90 & 90.17 & 89.09 & 72.98 \\
\hline 2010 & 128.65 & 95.77 & 95.19 & 129.23 \\
\hline 2011 & 113.55 & 95.16 & 98.45 & 110.27 \\
\hline 2012 & 121.15 & 103.37 & 107.59 & 116.93 \\
\hline 2013 & 103.44 & 86.86 & 91.96 & 98.34 \\
\hline
\end{tabular}

\section{Volume 7 Issue 12, December 2018}




\section{International Journal of Science and Research (IJSR)}

ISSN: 2319-7064

Index Copernicus Value (2016): 79.57 | Impact Factor (2017): 7.296

\begin{tabular}{|c|c|c|c|c|}
2014 & 118.01 & 78.91 & 117.59 & 79.33 \\
\hline 2015 & 147.84 & 85.37 & 114.67 & 118.53 \\
\hline 2016 & 141.92 & 89.59 & 107.77 & 123.74 \\
\hline 2017 & 136.48 & 90.77 & 112.60 & 114.65 \\
\hline 2018 & 146.15 & 103.49 & 108.02 & 141.61 \\
\hline Mean & $\mathbf{1 2 2 . 9 1}$ & $\mathbf{9 1 . 9 5}$ & $\mathbf{1 0 4 . 2 9}$ & $\mathbf{1 1 0 . 5 6}$ \\
\hline Median & $\mathbf{1 2 4 . 9 0}$ & $\mathbf{9 0 . 4 7}$ & $\mathbf{1 0 7 . 6 8}$ & $\mathbf{1 1 5 . 7 9}$ \\
\hline
\end{tabular}

Table 3 shows the value of measures of profitability which are profit on sales ratio, earning per share, return on equity and total sales for the period of 10 years.

Table 3: Profitability Measures

\begin{tabular}{|c|c|c|c|c|}
\hline Year & Total Sales & $\begin{array}{c}\text { Profit on } \\
\text { sales Ratio }\end{array}$ & $\begin{array}{c}\text { Earnings per } \\
\text { Share }\end{array}$ & $\begin{array}{c}\text { Return On } \\
\text { Equity }\end{array}$ \\
\hline 2009 & $28,064.40$ & 4.45 & 23.9 & 464.73 \\
\hline 2010 & $32,017.40$ & 16.35 & 97.09 & 1879.28 \\
\hline 2011 & $42,299.90$ & 14.71 & 20.63 & 2138.47 \\
\hline 2012 & $43,787.30$ & -0.97 & -1.46 & -146.37 \\
\hline 2013 & $55,695.00$ & 8.90 & 17.04 & 1703.26 \\
\hline 2014 & $72,695.30$ & 16.12 & 40.24 & 4020.89 \\
\hline 2015 & $82,448.40$ & 18.39 & 52.01 & 5192.97 \\
\hline 2016 & $93,227.60$ & 17.37 & 27.73 & 2767.72 \\
\hline 2017 & $97,812.10$ & 22.27 & 29.16 & 3718.33 \\
\hline 2018 & $103,031.50$ & 17.59 & 30.94 & 3093.99 \\
\hline Mean & $\mathbf{6 5 1 0 7 . 8 9}$ & $\mathbf{1 3 . 5 2}$ & $\mathbf{3 3 . 7 2 8}$ & $\mathbf{2 4 8 3 . 3 2}$ \\
\hline Median & $\mathbf{6 4 1 9 5 . 1 5}$ & $\mathbf{1 6 . 2 3}$ & $\mathbf{2 8 . 4 4 5}$ & $\mathbf{2 4 5 3 . 0 9}$ \\
\hline
\end{tabular}

\section{Correlation Analysis}

To know the relationship between variable Pearson's Correlation Analysis has been applied. Table 4 shows the result of correlation between the measures of working capital and profitability of the company.

Table 4: Pearson's Correlation Analysis

\begin{tabular}{|c|c|c|c|c|}
\hline \multicolumn{5}{|c|}{ Correlation Analysis } \\
\hline & $\begin{array}{c}\text { Number of } \\
\text { Days in } \\
\text { Receivable }\end{array}$ & $\begin{array}{c}\text { Number of } \\
\text { Days in } \\
\text { Inventory }\end{array}$ & $\begin{array}{c}\text { Number of } \\
\text { Days in } \\
\text { Payable }\end{array}$ & $\begin{array}{c}\text { Cash } \\
\text { Conversion } \\
\text { Cycle }\end{array}$ \\
\hline $\begin{array}{c}\text { Profit on sales } \\
\text { Ratio }\end{array}$ & 0.65 & -0.30 & 0.46 & 0.38 \\
\hline Earnings per Share & 0.28 & -0.17 & -0.02 & 0.51 \\
\hline Return On Equity & 0.64 & -0.52 & 0.69 & 0.18 \\
\hline Total Sales & 0.74 & -0.10 & 0.72 & 0.42 \\
\hline
\end{tabular}

\section{Findings and Suggestions}

In reference of table 2 , the average of cash conversion cycle is 110.56 days it means that company has mostly completed 2 cycles in a year. The company has shortest cycle in the year 2008-09 and longest in the year 2017-18 that indicates change in policy to maintain the cash conversion cycle of the business.

In reference of table 3, the average of total sales is 65107.89 million. The company achieved highest sales in the year 2016-17 and lowest in the year 2008-09 but the company earned maximum profit on sales in the year 2016-17 and minimum in the year 2011-12. The average value of profit on sales is $13.52 \%$.

In reference of table 4 , correlation analysis clearly indicates that there is a strong positive relationship between number of

days receivable and profit on sales ratio which means that company attract more and more customers by allowing credit period. In other words, company can increase their profit by giving more days to debtor for settlement of their outstanding. Number of days in receivable also have positive relationship with Return on equity and total sales.

Researcher observed negative association between number of days in inventory and profitability of the company; it means that shorter days in inventory may increase the profitability of the company.

Number of days in payable is also positively related with profitability of the company. It indicates that company efficiently use credit period given by the creditor. If creditors allow more days for repayment than before then it may increase the profitability of the company.

Cash conversion cycle has positive but moderate degree of correlation with profitability of the firm. Hence, Both the null hypothesis is not accepted.

\section{Conclusion}

The survival of business becomes possible only if it is able to make profit. Loss is also part of business but the company should have enough strength to overcome from the loss. To run the business smoothly is a challenge for every manager. Working capital is required for day to day operation of the business. To know the link between profitability and working capital, researcher has been select Aurobindo Pharma which is listed Pharmaceutical Company of India. For this study, the financial data of company for 10 years from 2008-09 to 2017-2018 have been taken. The financial data has been analyzed by using ratio analysis technique and empirically investigated by using correlation between the variables.

The findings indicate a strong positive relationship between number of days receivable and profit on sales ratio which means that company attract more and more customers by allowing credit period.

\section{References}

[1] Deloof, M. (2003). Does working capital management affect profitability of Belgian firms?. Journal of business finance \& Accounting, 30(3-4), 573-588.

[2] Lazaridis, I., \& Tryfonidis, D. (2006). RELATIONSHIP BETWEEN WORKING CAPITAL MANAGEMENT AND PROFITABILITY OF LISTED COMPANIES IN THE ATHENS STOCK EXCHANGE. Journal of Financial Management \& Analysis, 19(1), 26

[3] Alipour, M. (2011). Working capital management and corporate profitability: Evidence from Iran. World applied sciences journal, 12(7), 1093-1099.

[4] Arunkumar, O. N., \& Ramanan, T. R. (2013). Working capital management and profitability: A sensitivity analysis. International Journal of Research and Development, 2(1), 52-58. 
[5] Enqvist, J., Graham, M., \& Nikkinen, J. (2014). The impact of working capital management on firm profitability in different business cycles: Evidence from Finland. Research in International Business and Finance, 32, 36-49.

[6] Pais, M. A., \& Gama, P. M. (2015). Working capital management and SMEs profitability: Portuguese evidence. International Journal of Managerial Finance, 11(3), 341-358.

[7] Sivashanmugam, C., \& Krishnakumar, S. (2016). Working capital management and corporate profitability: Empirical evidences from Indian cement companies. Asian Journal of Research in Social Sciences and Humanities, 6(7), 1471-1486.

[8] https://www.aurobindo.com/investors/. [Accessed: dec. 06, 2018].

\section{Author Profile}

Rupam Soni received the B.COM, M.COM (Accountancy \& Statistics) and M.COM (Business Administration) degrees from Govind Guru Govt. College, Banswara in 2013, 2015 and 2017, respectively. She had qualified UGC NET - JRF examination with Commerce subject in 2016. Now, she is working as a Junior Research Fellow at S D School of Commerce, Gujarat University, Ahmedabad 